\title{
KEDUDUKAN KREDITUR HAK TANGGUNGAN DALAM KEPAILITAN
}

\author{
Oleh \\ R.M. Taufik Husni*)
}

Abstrak

Dalam Undang-undang Hak Tanggungan menentukan jaminan hak tanggungan bagi kreditur untuk mengeksekusi secara langsung jaminan hak tanggungan yang dijadikan jaminan pelunasan terhadap utang dalam hal apabila debitur tidak dapat membayar utang-utangnya ataukah debitur sedang dalam proses dipailitkan. Akan tetapi dalam kenyataannya terjadi ketidak sinkronan dengan eksistensi UU-KPKPU, dimana kreditur memegang hak tanggungan tidak dapat langsung mengeksekusi jaminan hak tanggungan atas hutang debitur yang dipailitkan, tetapi diambil alih oleh kurator, bahkan dapat memperlakukan obyek hak tanggungan seolah-olah tidak terjadi kepailitan terhadap debitur dikarenakan UU-KPKPU mengambil dengan sewenang-wenang hak dari kreditur. Hal ini sangat berentangan dengan aturan yang ada dalam UUHT dimana setiap hak tanggungan dapat langsung di eksekusi dengan adanya Irah-irah eksekutorial terhadap setiap jaminan utang hak tanggungan.

\section{Kata Kunci : Kedudukan Kreditur, Kepailitan, Eksekusi Hak Tanggungan}

\section{A.PENDAHULUAN}

Dalam kehidupan masyarakat, yang telah mengenal uang sebagai alat pembayaran; dan juga dapat diketahui bahwa hampir semua masyarakat telah menjadikan kegiatan pinjam meminjam uang sebagai suatu yang sangat diperlukan untuk mendukung perkembangan ekonominya dan untuk meningkatkan taraf hidupnya. Dapat dikatakan bahwa pihak peminjam, meminjam uang kepada pihak pemberi jaminan untuk membiayai kebutuhan yang berkaitan dengan kehidupan sehari-hari atau untuk memenuhi keperluan dana guna pembiayaan kegiatan usahanya. Dengan demikian kegiatan pinjam meminjam telah menjadi bagian dari kehidupan masyarakat (M. Bahsan, 2007 : 1).

Berbagai lembaga keuangan, utamanya bank, ataupun lembaga keuangan lainnya dalam hal ketika memberikan jaminan dana kepada masyarakat ter-

*) Penulis adalah Dosen Program Pascasarjana Universitas Islam Syekh Yusuf masuk bunga hasil pinjaman, semua itu merupakan kompensasi pinjaman yang menjadi pendapatan yang diperoleh oleh pihak bank atau lembaga lainnya. Karena dana yang disalurkan merupakan dana masyarakat, maka bank dalam menyalurkannya kepada masyarakat selalu menggunakan prinsip kehati-hatian. Pada umumnya bank atau lembaga bukan bank lainnya tidak akan berani memberikan kredit kepada masyarakat tanpa adanya jaminan (collateral). Salah satu faktor yang membuat sistem perbankan nasional keropos adalah akibat mengabaikan prinsip kehati-hatian. Di samping faktor penunjang lain, yakni lemahnya pengawasan dari Bank Indonesia (BI) (A. Sawir dalam Lili Marheni, 2012, 20).

Sikap kehati-hatian itu dipandang perlu karena bank atau lembaga lain memiliki tingkat resiko yang sangat tinggi. Bisnis perbankan merupakan kegiatan menghitung, mengidentifikasikan, dan sekaligus mengatasi resiko agar menjadi 
managable. Apabila kreditur dan debitur telah membuat perjanjian, maka lahirlah hak dan kewajiban diantara kedua belah pihak. Kreditur berkewajiban menyerahkan uang yang diperjanjikan dengan hak untuk menerima kembali uang tersebut dari debitur tepat pada waktunya disertai bunga dan biaya (Lili Marheni, 2012; 20).

Fungsi dari jaminan utang adalah pemberian keyakinan kepada pihak kreditur atas pembayaran utang-utang yang telah diberikan kepada debitur, dimana hal ini terjadi karena hukum ataupun terbit dari suatu perjanjian yang bersifat asesoir terhadap perjanjian pokok terhadap perjanjian yang menerbitkan utang-piutang (Munir Fuadi, 2013; 8). Artinya memberikan hak penuh kepada bank sebagai kreditur untuk mendapatkan pelunasan dari barang yang dijaminkan, dimana apabila debitur tidak dapat melunasi utangnya atau cidera janji sehingga pembayarannya tidak tepat waktu sebagaimana yang diperjanjikan.

Oleh karena itu, Hukum Jaminan memiliki kaitan yang sangat erat dengan bidang hukum benda dan bidang hukum perbankan, dalam bidang perbankan, hukum jaminan berhubungan dengan fungsi perbankan sebagai penghimpun dan penyalur dana masyarakat dalam bentuk kredit. Lembaga Bank dan bukan bank di dalam menyalurkan pinjaman (kredit) mempunyai tingkat resiko (degree of risk) yang sangat tinggi, sehingga sudah selayaknyalah bertindak ekstra hati-hati dan obyektif di dalam menyetujui dan atau menolak permohonan pengajuan pinjaman (kredit) oleh pihak debitor.

Dalam perjanjian, terkait dengan hak dan kewajiban debitur bersifat timbal balik dengan hak dan kewajiban kreditur. Riskan bagi suatu bank dalam pemberian kredit kepada dunia usaha selalu terjadi tragedi seperti Monster Perbankan yang bernama Kredit Macet, sehingga resiko yang ditanggung bank sangat besar. Oleh karenanya, untuk mengamankan pe- ngembalian dana yang disalurkan perlu dilakukan pengikatan jaminan. Dalam Kitab Undang-undang Hukum Perdata (KUHPerdata), telah memberikan pengaman kepada kreditur dalam menyalurkan kredit kepada debitur, yaitu dengan memberikan jaminan khusus. Jaminan khusus berupa kebendaan yang diminta oleh bank dalam menyalurkan kredit merupakan realisasi dari prinsip kehati-hatian perbankan (prudential banking principle) (Muhammad Djumhana dalam Lili Marheni, 2012, 21).

Jaminan yang baik menurut Munir Fuadi, salah satunya adalah nilai suatu jaminan dapat meningkat dan cenderung relatif, dan jaminan tersebut mudah dinilai. Oleh karena itu, dalam prakteknya, terkait dengan jaminan yang paling banyak diminta oleh bank adalah berupa tanah, karena secara ekonomis tanah mempunyai prospek yang menguntungkan. Jaminan yang oleh lembaga perbankan dianggap paling efektif dan aman adalah tanah; dengan jaminan maka tepatnya adalah Hak Tanggungan. Perspektif tersebut menganggap bahwa kemudahan dalam mengidentifikasi akan obyek dari hak tanggungan itu sifat eksekusinya sangat jelas. Perspektif yang lain bahwa hutang yang dijamin dengan hak tanggungan harus dibayar terlebih dahulu dari tagihan lainnya dengan uang hasil pelelangan tanah yang menjadi obyek hak tanggungan.

Selain itu, kreditur Hak Tanggungan merupakan kreditur sparatis, yaitu yang diberikan kekuasaan atas jaminan kepadanya diberi oleh hukum hak mengeksekusi (Munir Fuadi, 2013; 95). Lebih lanjut lagi, bahwa Sertifikat Hak Tanggungan mempunyai title esekutorial, dan yang lebih penting lagi adalah hak tanggungan telah diatur dalam Undang-undang. Dalam dunia perbankan, perjanjian kredit yang tidak dialasi dengan Perjanjian Hak Tanggungan akan berdampak pada 
penanggungan resiko yang cukup tinggi terhadap pihak kreditur.

Dalam perjanjian hak tanggungan, disebutkan bahwa apabila debitur wanprestasi, kreditur dengan kekuasaan sendiri dapat menjual obyek hak tanggungan. Janji untuk menjual dengan kekuasaan sendiri (rieeling van eigenniachtige verkoop) dilaksanakan oleh kreditur tanpa melalui persetujuan (fiatexecutie) dari pengadilan negeri. Kreditur diberikan hak untuk menjual atas kekuasaan sendiri sesuai dengan yang telah diperjanjikan dalam Akta Pemberian Hak Tanggungan untuk dijual melalui pelelangan umum. Di samping itu, kreditur juga mempunyai hak memohonkan kepada pengadilan untuk mengeksekusi hak tanggungan berdasarkan Sertifikat Hak Tanggungan. Ketentuan tersebut diatur dalam Undangundang Nomor 4 Tahun 1996 Tentang Hak Tanggungan pada Pasal 20 ayat (1) bahwa : "Apabila debitur cidera janji, maka berdasarkan:

a. Hak pemegang hak tanggungan pertama untuk menjual obyek hak tanggungan sebagaimana dimaksud dalam Pasal 6; atau

b. Titel eksekutorial yang terdapat dalam sertifikat hak tanggungan sebagaimana dimaksud dalam Pasal 14 ayat (2).

Obyek hak tanggungan dijual melalui pelelangan umum menurut tata cara yang ditentukan dalam peraturan perundangundangan untuk pelunasan piutang pemegang hak tanggungan dengan hak mendahului daripada kreditur-krediturnya.

Berlakunya Undang-undang Nomor 37 Tahun 2004 Tentang Kepailitan dan Penundaan Kewajiban Pembayaran Utang yang selanjutnya disingkat dengan UUKPKPU sangatlah mempengarugi Lembaga Hak Tanggungan. Debitur yang mengalami kesulitan untuk membayar utangnya dan telah jatuh tempo, serta mempunyai minimal 2 (dua) kreditur, maka menurut hukum, debitur dapat dimohonkan kepailitan. Ketentuan Pasal 55 UU-KPKPU menentukan :

(1) Dengan tetap memperhatikan ketentuan sebagaimana dimaksud dalam Pasal 56, Pasal 57, Pasal 58, setiap kreditur pemegang gadai, jaminan fidusia, hak tanggungan, hipotik atau hak agunan atas kebendaan lainnya, dapat mengeksekusi haknya seolaholah tidak terjadi kepailitan".

Selanjutnya dalam Pasal 56 UUKPKPU menentukan :

(1) Hak eksekusi kreditur sebagaimana dimaksu dalam Pasal 55 ayat (1) dan hak pihak ketiga untuk menuntut hartanya yang berada dalam penguasaan Debitur Pailit atau Kurator, ditangguhkan untuk jangka waktu 90 (sembilan puluh) hari sejak tanggal putusan pernyataan pailit diucapkan.

(2) Penangguhan sebagaimana dimaksudkan dalam ayat (1) tidak berlaku terhadap tagihan kreditur untuk memperjumpakan utang.

(3) Selama jangka waktu penangguhan sebagaimana dimaksud pada ayat (1), Kurator dapat menggunakan harta pailit berupa benda tidak bergerak maupun benda bergerak atau menjual harta pailit yang berupa benda bergerak yang berada dalam penguasaan Kurator dalam rangka kelangsungan usaha debitur, dalam hal telah diberikan perlindungan yang wajib bagi kepentingan Kreditur dan pihak ketiga sebagaimana dimaksud pada ayat (1). (Jurnal-Siti-HeiranisyaCitra-Agca-0910110237, diakses tanggal 12 September 2014, pukul 10:30 WIB).

Dari ketentuan tersebut diatas, ada ketidaksinkronan antara Undang-undang Hak Tanggungan dan UU-KPKPU, hal ini terlihat dalam Pasal 55 ayat (1), yaitu kata seolah-olah yang dapat menimbulkan multi tafsir bahkan tidak jelas makna, seolah-olah itu seperti apa. Hal serupa dalam pasal 56 ayat (1) UU-KPKPU. 
Sebagai gambaran pada redaksi pasal 58 UU-KPKPU yang mengatakan kreditur pemegang gadai, jaminan fidusia, hak tanggungan, hipotik atau hak agunan atas kebendaan lainnya, ditangguhkan untuk jangka waktu 90 (sembilan pulu) hari sejak tanggal putusan pailit diucapkan. Hal itu sangat bertentangan dengan UU-HT dimana dalam perjanjian Hak Tanggungan disebutkan bahwa apabila debitur wanprestasi, kreditur dengan kekuasaan sendiri dapat menjual langsung obyek hak tanggungan, sebagai salah satu ciri dan preferensi dari sifat kreditur separatis yang diberikan kekuasaan atas jaminan kepadanya diberi oleh hukum hak mengeksekusi hak tanggungan dan merupakan perwujudan dari asas droitde preference. Akan tetapi, apabila hak jaminan kebendaan ditangguhkan selama 90 (sembilan puluh) hari dan diserahkan ke tangan kurator, maka kreditur pemegang hak jaminan tersebut tidak bisa lagi melaksanakan hak eksekusinya atas benda yang dijaminkan kepadanya, padahal setiap hak tanggungan memiliki title eksekutorial yang memberikan kekuasaan kepada kreditur untuk mengeksekusi benda jaminan dan kreditur untuk pelunasan utang yang tidak terbayarkan dimana title eksekutorial ini memiliki kekuatan sama dengan putusan pengadilan yang memiliki kekuatan hukum tetap, sebagaimana tercantum dalam pasal 14 ayat (1), (2), dan (3) Undang-undang Hak Tanggungan. Hal ini jelas bertentangan dengan prinsip hukum jaminan yang memberikan hak untuk mengeksekusi bagi pemegang jaminan kebendaan.

Hal serupa dalam ketentuan Pasal 59 Undang-undang KPKPU, juga bertentangan dengan Pasal 6 yang mengatakan : "apabila debitur cidera janji, pemegang hak tanggungan pertama mempunyai hak untuk menjual obyek hak tanggungan atas kekuasaannya sendiri melalui pele- langan umum serta mengambil pelunasan piutang dan hasil penjualan tersebut".

Hal serupa dalam Pasal 20 ayat (1), dan dipertegas di Pasal 21 Undangundang Hak Tanggungan. Menurut Pasal 21 Undang-undang Nomor 4 Tahun 1996 Tentang Hak Tanggungan, yang menentukan bahwa apabila pemberi hak tanggungan dinyatakan pailit, maka pemegang hak tanggungan tetap berwenang melakukan segala hak yang diperolehnya menurut ketentuan Undang-undang Hak Tanggungan. Dengan demikian, berarti bahwa Pasal 59 UU-KPKPU mengambil dengan sewenang-wenang hak dari kreditur pemegang hak tanggungan yang dijamin oleh Undang-undang Hak Tanggungan.

Dalam sistem Hukum Jaminan, sebaiknya tidak tumpang-tindih ataukah bertentangan satu sama lainnya, termasuk dengan Hukum Kepailitan. Antara UUHT dan UU-KPKPU sekilas terjadi tumpang-tindih, namun melihat kedua undang-undang ini dalam penerapannya harus ada pemisahan saat kapan penerapan UUHT dan penerapan UU-KPKPU diberlakukan, sehingga tidak diterapkan secara bersamaan yang akan menimbulkan persepsi tumpang-tindih kedua undang-undang tersebut.

\section{B. PEMBAHASAN}

\section{Pengaturan Eksekusi Hak Tanggungan Dalam Hal Debitur Cidera Janji (Wanprestasi)}

Sebelum dijelaskan tentang eksekusi hak tanggungan, maka perlu dijelaskan penggolongannya. Eksekusi adalah pelaksanaan putusan pengadilan yang telah mempunyai kekuatan hukum yang tetap. Yang dapat di eksekusi adalah salinan putusan dan grose akte (salinan pertama dan akta autentik). Sehingga proses disamakan dengan putusan pengadilan yang telah memperoleh kekuatan hukum 
yang tetap, yang memuat title eksekutorial, dengan demikian dapat dieksekusi (Sudikno Mertokusumo, 1986; 6).

Eksekusi hak tanggungan diatur dalam Pasal 20 Undang-undang Nomor 4 Tahun 1996. Latar belakang lahirnya eksekusi ini adalah disebabkan pemberian hak tanggungan atau debitur tidak melaksanakan prestasinya sebagaimana mestinya, walaupun yang bersangkutan telah diberikan somasi 3 (tiga) kali berturut-turut oleh kreditur. Dalam Pasal 20 Undang-undang Nomor 4 Tahun 1996, diatur tentang tata cara eksekusi hak tanggungan, yaitu dengan 3 cara, yaitu (H. Salim HS; 2004; 190-191):

1. Hak pemegang hak tanggungan pertama untuk menjual hak tanggungan atas kekuasaan sendiri melalui pelelangan umum sebagaimana dimaksud pada Pasal 6. Hak untuk menjual obyek hak tanggungan atas kekuasaan sendiri adalah suatu perwujudan dari kedudukan diutamakan yang dipunyai oleh pemegang hak tanggungan atau pemegang hak tang-gungan pertama, bahwa apabila debitur cidera janji, pemegang hak tanggungan berhak untuk menjual obyek hak tanggungan melalui pelelangan umum tanpa memerlukan persetujuan lagi dari pemberi hak tanggungan, dan selanjutnya mengambil pelunasan piutangnya dari hasil penjualan itu lebih dahulu dari kreditur yang lain.

2. Eksekusi atas title eksekutorial yang terdapat pada sertifikat Hak Tanggungan, sebagimana yang dimaksud dalam Pasal 14 ayat (2). Irah-irah (kepala keputusan) yang dicantumkan pada sertifikat hak tanggungan dimaksudkan untuk menegaskan adanya kekuatan eksekutorial pada sertifikat hak tanggungan, sehingga apabila debitur cidera janji, siap untuk dieksekusi seperti halnya suatu putusan pengadilan yang telah mem- punyai kekuatan hukum yang tetap, melalui tata cara dengan menggunakan lembaga parate executive sesuai dengan Hukum Acara Perdata.

3. Eksekusi akta di bawah tangan, adalah penjualan obyek hak tanggungan yang dilakukan oleh pemberi hak tanggungan, berdasarkan kesepakatan dengan pemegang hak tanggungan, jika dengan cara ini akan diperoleh harga yang tinggi.

\section{Kedudukan Yang Diutamakan Bagi Kreditur Pemegang Hak Tanggungan}

Hak istimewa bagi kreditur hak tanggungan dalam suatu proses kepailitan, baik dalam hak kepailitan kreditur hipotik, fudisia, dan gadai, adalah bahwa kreditur pemegang hak tanggungan merupakan kreditur preferens dapat diuraikan bahwa kreditur pemegang hak tanggungan harus dibayar hutangnya lebih dahulu sebelum dibayar pada kreditur lain (Munir Fuadi, 2013; 94-95).

Undang-undang Hak Tanggungan dengan sangat jelas menyebutkan kreditur hak tanggungan sebagai kreditur preferen diatur dalam Pasal 1 ayat (1) UUHT Nomor 4 Tahun 1996 yang menyebutkan bahwa : "Hak tanggungan atas tanah serta benda-benda yang berkaitan dengan tanah adalah hak jaminan yang dibebankan pada hak atas tanah berikut atau tidak berikut benda-benda lain yang merupakan satu kesatuan dengan tanah itu untuk pelunasan utang tertentu yang memberikan kedudukan terhadap kreditur-kreditur lainnya".

Di dalam Hukum Jaminan, pengertian tentang "kedudukan yang diutamakan" menurut penjelasan umum Undangundang Hak Tanggungan Nomor 4 Tahun 1996 adalah jika dibitur cidera janji, kreditur pemegang hak tanggungan berhak menjual melalui pelelangan umum tanah yang dijadikan jaminan menurut ketentuan peraturan perundang-undang- 
an yang bersangkutan, dengan hak mendahului dari pada kreditur-kreditur yang lain. Kedudukan diutamakan tersebut sudah barang tentu tidak mengurangi preferensi piutang-piutang negara menurut ketentuan-ketentuan hukum yang berlaku.

Mengenai posisi diutamakannya kedudukan kreditur pemegang hak tanggungan daripada kreditur yang lain, dijelaskan dalam Undang-undang Hak Tanggungan Nomor 4 Tahun 1996, Pasal 20 ayat (1), apabila debitur cidera janji, maka pemegang hak tanggungan berhak menjual obyek hak tanggungan melalui pelelangan umum sesuai dengan tata cara yang ditentukan oleh peraturan perundang-undangan yang berlaku untuk pelunasan piutang pemegang hak tanggungan dengan mendahului daripada kreditur-kreditur lainnya. Oleh karena itu, maka setiap kreditur yang memegang hak tanggungan dari debitur memiliki hak untuk melaksanakan parate eksekusi, artinya pemegang hak tanggungan tidak perlu bukan saja memperoleh persetujuan dari pemberi hak tanggungan, tetapi juga tidak perlu meminta penetapan dari pengadilan setempat apabila akan melakukan eksekusi atas Hak Tanggungan yang menjadi jaminan utang debitur dalam hal debitur ingkar janji (Tesis Harnoto Roseno, 2008; 44, diakses tanggal 12 September 2014, pukul 10:30 WIB).

\section{Kedudukan Kreditur Pemegang Hak Tanggungan Dalam Hal Debitur Pailit}

Kreditur pemegang hak tanggungan dalam kedudukannya sebagai kreditur preferen, pada prinsipnya mendapat kedudukan didahulukan dibandingkan dengan kreditur-kreditur lainnya.

Menurut J. Satrio memberikan penjelasan tentang hak didahulukan di sini adalah sebagai berikut : "Didahulukan disini adalah didahulukan dalam mengambil pelunasan atas penjualan eksekusi benda hipotik (hak tanggungan). Bahwa kedudukan "preferen" (lebih didahulukan) berkaitan dengan hasil eksekusi, akan tampak jelas kalau kita hubungkan dengan Pasal 1132 KUHPerdata, yang mengatakan bahwa pada asasnya para kreditur berbagi pond's-pond's harta benda milik debitur. Dengan memperjanjikan dan memasang hak tanggungan - dulu hipotik, maka kreditur menjadi preferen atas hasil penjualan benda tertentu milik debitur atau milik pemberi jaminan yang diberikan sebagai jaminan khusus, dalam arti, menyimpang dari asas Pasal 132 KUHPerdata tersebut di atas, ia berhak mengambil lebih dahulu uang hasil hipotik. (www.Vol.II/No.2/ Januari-Maret/2014 Edisi Khusu Montolalu F. Kajian Terdapat/pdf.

Apa yang dilakukan Satrio, dapat disimpulkan bahwa yang menjadi unsur dari kedudukan yang diutamakan atau didahulukan dari kreditur pemegang hak tanggungan adalah berkaitan dengan pelunasan piutang kreditur pemegang hak tanggungan, dan cara pelunasannya yaitu dengan cara penjualan lelang terhadap tanah yang menjadi obyek hak tanggungan (eksekusi hak tanggungan). Dalam Penjelasan Umum Undang-undang Hak Tanggungan Nomor 4 Tahun 1996, khususnya penjelasan angka 4 pada alinea 2 terdapat adanya perkecualian dari kedudukan yang diutamakan (preferen) dari pihak kreditur pemegang hak tanggungan, yaitu, bahwa kedudukan diutamakan kreditur pemegang hak tanggungan tidak mengurangi preferensi piutang-piutang negara menurut ketentuan hukum yang berlaku. Dengan demikian, kedudukan yang diutamakan, kreditur pemegang hak tanggungan dikalahkan oleh piutang negara. Dalam hal piutang negara yang mengalahkan kreditur pemegang hak tanggungan, Sjahdeini berpendapat bahwa, berpedoman kepada ketentuan Pasal 1137 KUHPerdata, piutang negara yang kedudukannya lebih 
tinggi dari hak tanggungan sebagaimana dimaksud dalam Penjelasan Umum Undang-undang Hak Tanggungan hanya pajak saja (Sutan Remi Sjahdeini, op cit hlm. 89-90).

Menurut Setiawan, Hak Separatis adalah "hak yang diberikan oleh hukum kepada kreditur pemegang hak tanggungan, bahwa barang jaminan (agunan) tidak termasuk harta pailit" (Setiawan, Hak Tanggungan dan Masalah Eksekusinya, Varia Peradilan, Majalah Hukum, Tahun XI No. 131, Agustus 1996, halaman 145).

Kreditur separatis adalah kreditur yang memiliki jaminan hutang kebendaan (hak jaminan), seperti pemegang hak tanggungan, hipotik, gadai, fidusia, dan lain-lain (Pasal 56 Undang-undang Nomor 37 Tahun 2004 Tentang KPKPU). Kreditur dengan jaminan yang bukan jaminan kebendaan (seperti garansi, termasuk garansi bank) bukan merupakan kreditur separatis. Dengan demikian yang dimaksudkan dengan hak kreditur separatis adalah hak yang diberikan oleh hukum kepada kreditur pemegang hak jaminan untuk tetap dapat melaksanakan hak-hak eksekusinya meski debiturnya dinyataan pailit.

Dalam ketentuan Pasal 55 ayat (1) Undang-undang KPKPU, nampaknya undang-undang ini mengakui hak separatis dan kreditur pemegang hak tanggungan, tetapi akan menjadi kontradiktif setelah melihat ketentuan Pasal 56 ayat (1) Undang-undang KPKPU yang menyatakan : "Hak eksekusi kreditur sebagaimana dimaksud dalam Pasal 55 ayat (1) dan hak pihak ketiga untuk menuntut hartanya yang berada dalam penguasaan debitur pailit atau kurator, ditangguhkan untuk jangka waktu 90 (sembilan pulu) hari sejak tanggal putusan pernyataan pailit diucapkan".

Kedua ketentuan tersebut di atas justru menjadi bertentangan dengan hak separatis dari pemegang jaminan yang diakui oleh Pasal 55 ayat (1) itu, yang menyatakan bahwa penagguhan yang dimaksudkan dalam ketentuan ini bertujuan antara lain :

1. Untuk memperbesar kemungkinan tercapainya pedamaian; atau

2. Untuk memperbesar kemungkinan mengoptimalkan harta pailit; atau

3. Untuk memperbesar kemungkinan kurator melaksanakan tugasnya secara optimal.

Selama waktu penangguhan, segala tuntutan hukum untuk memperoleh pelunasan piutang tidak dapat diajukan dalam persidangan, serta baik kreditur maupun pihak ketiga tidak dibenarkan mengeksekusi atau memohonkan sita atas benda yang menjadi agunan (Sutan Remi Sjahdeini, op cit, hlm. 9).

Tujuan Pasal 56 ayat (1) tersebut bahwa penangguhan dimaksud agar memperbesar kemungkinan mengoptimalkan harta pailit adalah bertentangan dengan hak separatis dari Pasal 21 Undang-undang Hak Tanggungan, sebab sesuai Pasal 21 Undang-undang Hak Tanggungan tersebut menentukan bahwa apabila pemberi hak tanggungan dinyatakan pailit, maka pemegang hak tanggungan tetap berwenang melakukan segala hak yang diperolehnya menurut ketentuan Undang-undang Hak Tanggungan. Dengan demikian terlihat bahwa hak kreditur hak tanggungan telah dirampas dengan sewenang-wenang oleh UUKPKPU Pasal 56 ayat (1), sehingga terlihat tidak konsisten, dimana di satu sisi ketentuan Pasal 55 ayat (1) nampaknya mengikuti hak separatis dan kreditur preferen, tetapi di sisi lain ketentuan Pasal 56 ayat (3) justru mengingkari hak separatis itu karena menentukan bahwa barang yang dibebani dengan hak jaminan termasuk hak tanggungan merupakan harta pailit. Artinya bahwa Undang-undang Kepailitan tidak memisahkan benda-benda yang dibebani hak 
jaminan sebagai benda-benda bukan merupakan harta pailit.

Permasalahan lainnya dalam UUKPKPU Pasal 59 ayat (1) bahwa dengan tetap memperhatikan Pasal 56 kreditur pemegang hak jaminan termasuk pemegang hak tanggungan "harus" melaksanakan haknya tersebut dalam jangka waktu 2 (dua) bulan sejak dimulainya insolvensis sebagaimana dimaksud dalam Pasal 178 ayat (1). Selanjutnya dalam Pasal 59 ayat (2) ditentukan apabila setelah lewat jangka waktu 2 (dua) bulan tersebut, kreditur pemegang hak jaminan (termasuk kreditur pemegang hak tanggungan) tidak dapat melaksanakan haknya, maka kurator "harus" menuntut diserahkannya barang yang menjadi agunan untuk selanjutnya dijual sesuai dengan cara sebagaimana dimaksud dalam Pasal 185 Undang-undang Nomor 37 Tahun 2004 Tentang KPKPU, tanpa mengurangi hak pemegang hak tersebut untuk memperoleh hasil penjualan agunan.

Dari ketentuan kedua pasal tersebut diatas, yaitu Pasal 29 ayat (1) dan ayat (2), memberikan kewenangan yang semu karena terdapat batasan waktu yang singkat bagi kreditur untuk mengeksekusi haknya, ditambah lagi dengan pemaknaan gramatikal dari kata "harus" mengandung makna yang bersifat memaksa dan mengikat kreditur. Dengan demikian apabila setelah debitur sudah dinyatakan insolvensi, maka terhitung sejak hari itu juga kreditur pemegang hak tanggungan harus dapat menjual obyek hak pemegang tanggungan dengan tata cara sebagaimana yang ditentukan oleh Pasal 20 Undang-undang Nomor 4 Tahun 1996 tentang Hak Tanggungan, jika dalam waktu 2 (dua) bulan tidak terjual maka harus diserahkan kepada Kurator sesuai dengan mekanisme Undangundang Nomor 37 Tahun 2004 Tentang KPKPU.

\section{Pelaksanaan Hak Kreditur Hak Tanggungan Berdasarkan Pasal 59 Undang-undang Kepailitan}

Dalam pasal 59 ayat (1) UUK menyebutkan bahwa : "Kreditur Pemegang Hak Tanggungan harus melaksanakan haknya (mengeksekusi hak tanggungan) dalam jangka waktu paling lambat 2 (dua) dua bulan setelah dimulainya insolvensi (keadaan bangkrut). Oleh karena itu, seakan-akan dapat mengeksekusi haknya seolah-olah tidak terjadi kepailitan (Ahmad Yani dan Gunawan Widjaja, 2002; 56).

Meskipun secara prinsip, kepailitan tidak menghalangi dilaksanakannya eksekusi atas jaminan preferen, selama kurator dapat memberi jaminan perlindungan yang wajar, pasal 56A ayat (1) memberikan hak kepada kreditur untuk menangguhkan eksekusi untuk jangka waktu selama-lamanya 90 (sembilan puluh) hari terhitung sejak tanggal putusan kepailitan ditetapkan.

Penjelasan Pasal 56A ayat (1) menyebutkan bahwa penangguhan dilakukan dengan tujuan untuk memperbesar kemungkinan perdamaian atau mengoptimalkan harta pailit. Maka selama berlangsungnya jangka waktu penangguhan, maka segala tuntutan hukum untuk memperoleh pelunasan atas suatu piutang tidak dapat diajukan dalam sidang badan peradilan, dan pihak kreditur ataupun pihak ketiga dilarang mengeksekusi atau memohon sita barang menjadi agunan.

Dilanjutkan dengan ketentuan Pasal 59 ayat (2) UUK, yaitu : "Setelah lewat jangka waktu sebagaimana dimaksud pada ayat (1), kurator harus menuntut diserahkan benda yang menjadi agunan untuk selanjutnya dijual dengan tata cara sebagaimana dimaksud dalam pasal 185".

Dari ketentuan Pasal 59 ayat (1) UUK ini, dilihat dari penafsiran gramatikal dengan kata "harus" merupakan ketentuan yang bersifat memaksa dan mengikat 
kreditur pemegang hak tanggungan, sehingga kreditur pemegang hak tanggungan tidak dapat menyimpanginya. Dengan demikian apabila setelah debitur sudah dinyatakan insolvensi, maka terhitung sejak hari itu juga kreditur pemegang hak tanggungan harus dapat menjual obyek hak tanggungan dengan tata cara sebagaimana yang ditentukan oleh Pasal 20 UUHT jo Pasal 60 UUK.

Setelah debitur dinyatakan insolvensi, kedudukan obyek hak tanggungan adalah sebagai harta di luar harta (budel) pailit, akan tetapi hak eksekusi kreditur pemegang hak tanggungan terhadap obyek hak tanggungan dibatasi waktunya oleh ketentuan dalam UUK yang diambil alih oleh kurator setelah melewati jangka waktu 2 (dua) bulan. Dengan demikian pasal 59 ayat (1) dan ayat (2) UUK ini telah membatasi wewenang kreditur pemegang hak tanggungan untuk melaksanakan hak-haknya berdasarkan Pasal 20 ayat (1) UUHT. Dengan demikian berarti bahwa Pasal 59 UUK mengambil dengan sewenang-wenang hak dari kreditur pemegang hak tanggungan yang dijamin oleh Undang-undang Hak Tanggungan. Keadaan yang demikian menunjukkan adanya konflik norma yang menimbulkan ketidak pastian hukum bagi pelaku ekonomi khususnya pemegang hak jaminan antara UUK dengan UUHT yang menganut tentang hak kreditur separatis.

\section{PENUTUP}

Kepailitan berarti keadaan yang terjadi kepada debitur yang berhenti membayar, baik karena kondisisinya dalam keadaan tidak mampu membayar atau karena keadaan tidak mau membayar. Sehingga status agunan debitur yang dinyatakan pailit akan kehilangan hak penguasaan harta bendanya akan diserahkan penguasaannya kepada kurator dengan pengawasan seorang hakim pengadilan yang ditunjuk.

Kedudukan dan hak eksekusi kreditur dalam pelaksanaan eksekusi obyek hak tanggungan didasarkan pada 2 (dua) peraturan perundang-undangan yang saling bertentangan, yaitu eksekusi menurut pasal 20 ayat (1) huruf b Undangundang Hak Tanggungan dimana kreditur memegang hak tanggungan berhak menjual obyek hak tanggungan berdasarkan ketentuan eksekutorial sertifikat hak tanggungan yang dipertegas dengan Pasal 21 Undang-undang Hak Tanggungan dimana debitur pailit, kreditur pemegang hak tanggungan tetap melaksanakan hak-haknya. Sedangkan di sisi lain dalam Pasal 55 ayat (1) UU-KPKPU yang menyatakan bahwa kreditur pemegang hak tanggungan harus melaksanakan haknya (mengeksekusi hak tanggungan) dalam jangka waktu paling lambat 2 (dua) dua bulan setelah dimulainya insolvensi (keadaan bangkrut) khususnya terutama pada sebuah Perseroan Terbatas. Sebagaimana tercantum dalam Pasal 59 ayat (1) Undang-undang Kepailitan Nomor 37 Tahun 2004, menjelaskan bahwa hak tanggungan yang ada dibawah kekuasaan kreditur hanya memiliki waktu 2 (dua) bulan untuk melaksanakan eksekusinya jaminan terhitung sejak keadaan insolvensi sebagaimana dimaksud dalam Pasal 178 ayat (1) Undang-undang Kepailitan Nomor 37 Tahun 2004. Apabila dalam jangka waktu tersebut debitur belum melaksanakan eksekusinya, maka Kurator harus menuntut diserahkannya benda yang menjadi agunan untuk selanjutnya dijual dengan tata cara sebagimana dimaksud dalam Pasal 185, tanpa mengurangi hak kreditur pemegang hak tersebut atas hasil penjualan agunan tersebut (Pasal 59 ayat (2)). 


\section{DAFTAR PUSTAKA}

Ahmad Yani dan Gunawan Widjaja, 2002. Seni Hukum Bisnis Kepailitan, Jakarta, PT Rajawali Pers.

H. Salim HS, 2004. Perkembangan Hukum di Indonesia, Jakarta; PT Rajawali Pers.

M. Bahsan, 2007. Hukum Jaminan dan Jaminan Kredit Perbankan Indonesia, Jakarta; PT Rajawali Pers.

Munir Fuadi, 2013. Hukum Jaminan Hutang, Jakarta; Erlangga.

Sudikno Mertokusumo, 1986, Hukum Acara Perdata Indonesia, Yogyakarta; Liberty.

Sutan Remy Sjahdeini, 1996, Hak Tanggungan Asas-asas, Ketentuan-ketentuan Pokok dan Masalah Yang Dihadapi Oleh Perbankan, op cit.

Setiawan, 1996, Hak Tanggungan dan Masalah Eksekusinya. Varia Peradilan, Majalah Hukum Tahun XI No.131, Agustus 1996.

Siti Heiranisya Cita Agce, 2013. Jurnal pdf. Harmonisasi Pasal 21
Undang-undang Hak Tanggungan dengan Pasal 56 dan Pasal 59 Undang-undang Kepailitan dan Penundaan Kewajiban Pembayaran Utang Terkait Kreditur Separatis Pemegang Hak Tanggungan Yang Melekat Pada Benda Jaminan.

Lili

Marheni, 2012. www.pps.unud.ac.id/thesis_thesis /unud-392-883275-42-tesis.

Harinoto Roseno, 2008. Akibat Hukum Putusan Pernyataan Pailit Bagi Debitur terhadap Kreditur Pemegang Hak Tanggungan. www.Tesis/pdf/B4B006080/undi p.2008.

Franklin

Montolalu, 2014. www.Vol.II/No.2/JanuariMaret/2014 Edisi Khusus : Kajian Hukum Terhadap/pdf.kajian hukum terhadap pemegang hak tanggungan debitur yang telah dinyatakan pailit, Manado, Universitas Sam Ratulangi 